J. Clin. Chem. Clin. Biochem.

Vol. 18, 1980, pp. 279-285

\title{
Metabolic and Structural Studies on Serum- and Liver-Glycosaminoglycans in Normal and Liver-injured Rats
}

\author{
By A. M. Gressner, W. Köster-Eiserfunke, E. Van de Leur and H. Greiling
}

Department of Clinical Chemistry and Pathobiochemistry of the Medical Faculty of the RWTH Aachen, FRG

(Received August 20/November 21, 1979)

Summary: The incorporation of $\left[{ }^{35} \mathrm{~S}\right]$ sulfate into total and specific types of serum glycosaminoglycans was studied in rats with acute, subacute or chronic liver injury (liver cirrhosis), and compared with that of normal rats. The macromolecular (protein-bound) nature of serum glycosaminoglycans in normal and diseased animals was also analysed.

The results show a strong increase in rate and extent of $\left[{ }^{35} \mathrm{~S}\right]$ sulfate incorporation into total serum glycosaminoglycans for acutely but a decrease for subacutely and chronically liver damaged rats. The time-course of distribution of label between serum chondroitin sulfate and dermatan sulfate exhibits significant changes in liver-injured animals, in particular a relatively high proportion of dermatan $\left[{ }^{35}\right.$ S $]$ sulfate in rats with cirrhotic livers.

In comparison with serum glycosaminoglycans the labeling profile of glycosaminoglycans in the cirrhotic liver was quite different (heparan sulfate:dermatan sulfate:chondroitin sulfate $=1: 0.34: 0.09$ ) and changed only insignificantly during a $1 \mathrm{~h}$ labeling period.

The protein-bound moiety of serum glycosaminoglycans was not affected by liver disease; but the elution profile of chondroitin $\left[{ }^{35}\right.$ S] sulfate from Dowex $1 \times 2$ for treated rats was altered, thus indicating a structural modification of its carbohydrate chain.

Metabolische und strukturelle Untersuchungen der Glykosaminoglykane im Serum, im Vergleich zur Leber, bei normalen und leber-geschädigten Ratten

Zusammenfassung: Der Einbau von [ ${ }^{35}$ S] Sulfat in die gesamten und spezifischen Typen der Glykosaminoglykane im Serum vọ Ratten mit akuter, subakuter oder chronischer (Lebercirrhose) Leberschädigung wurde untersucht und mit dem gesunder Tière verglichen. Zusätżlich wuirden Untersuchungen zur makromolekularen, insbesondere zur proteingebundenen Striktur der Glykosaminoglykane im Serum normaler uñ lebergeschädigter Ratten durchgeführt.

Die Ergebnissse zeigen einen starken Anstieg der Rate und des Ausmaßes der Sulfatinkorporation in die gesamten Glykosaminoglykane im Serum bei akut, eine Erniedrigung jedoch bei subakut und chronisch lebergeschädigten Ratten. Der zeitliche Verlauf der Verteilung der [ ${ }^{35}$ S]Markierung zwischen Chondroitinsulfat und Dermatansulfat im Serum ließ signifikante Veränderungen bei lebergeschädigten Tieren erkennen, insbesondere einen relativ hohen Anteil von Dermatan $\left[{ }^{35}\right.$ S $]$ sulfat bei Ratten mit Lebercirrhoșe.

Im Vergleich zu Glykosaminoglykanen im Serum war das Markierungsprofil der Glykosaminoglykane in cirrhotischer Lebẹ sehr verschieden (Heparansulfat:Dermatansulfat:Chondroitinsulfat $=1: 0.34: 0.09$ ) und veränderte sich während einer 1-stündigen Markierungsperiode nur geringfügig.

Die proteingebundene Struktur der Glykosaminoglykane im Serum wurde durch experimentelle Lebererkrankungen nicht beeinflußt, jedoch weist die Änderung des Elutionsprofils von Chondroitin[ $\left[{ }^{35}\right.$ S $]$ sulfat an Dowex $1 \times 2$ auf struktưrelle Veränderungen seiner Kohlenhydratkette bei Leberschädigung hin. 


\section{Introduction}

Previous studies on the metabolism of hepatic glycosaminoglycans have shown that rat liver slices synthesize predominantly heparan sulfate and to a much smaller degree chondroitin sulfate, hyaluronic acid and a keratan sulfate-like fraction $(1,2)$. Both normal and damaged liver parenchyma, however, seem to be unable to incorporate $\left[{ }^{14} \mathrm{C}\right]$ amino sugar into dermatan sulfate $(1-3)$, although the latter is present in normal liver and shows a high accumulation in injured liver tissue (4-8).

Consequently the hypothesis was put forward that dermatan sulfate is synthesized in extrahepatic tissues, secreted and transported in the serum and taken up by the liver $(3,9)$. Because such a metabolic pathway would be of great importance for the pathogenesis of the fibrotic transition of chronically injured liver tissue, we studied the metabolism of total and specific types of sulfated glycosaminoglycans in serum of normal and liver-injured rats, compared it with that in liver. In addition, we investigated the structure of the macromolecular, in particular protein-bound nature of serum glycosaminoglycans.

\section{Materials and Methods}

\section{Materials}

Chondroitin AC (EC 4.2.2.5) and ABC (EC 4.2.2.4) lyases were obtained from Seikagaku Kogyo Comp., Tokyo, Japan; papain (EC 3.4.22.2, crystalline suspension, $30 \mathrm{U} / \mathrm{mg}$ protein) was from Boehringer Mannheim GmbH, Germany; thioacetamide p.a. was from Merck AG, Darmstadt, Germany; $D-\left[1-{ }^{14}\right.$ C $]$ glucosamine hydrochloride $(288.6 \mathrm{GBq} / \mathrm{mol})$ and sodium $\left[{ }^{35} \mathrm{~S}\right]$ sulfate (carrier free) were from New England Nuclear Corp., Boston, USA; Sephadex G-100 and Sepharose CL-4B were from Pharmacia, Uppsala, Sweden; Dowex $1 \times 2$ and Bio-Gel P 2 were from BioRad Laboratories, Munich, Germany.

\section{Treatment of rats}

Male Sprague-Dawley rats (250-320 g; Zentralinstitut für Versuchstiere, Hannover, FRG) received food and water ad libitum. Acute liver injury was induced by two repeated intraperitoneal thioacetamide injections of $100 \mathrm{mg} / \mathrm{kg}$ in a $24 \mathrm{~h}$ interval. One day after the last injection the rats were sacrificed. Subacute and chronic liver injury was produced by oral administration of thioacetamide for 4 weeks and 10 months, respectively, as described previously (2).

In general, each value represents the mean of two to four independent experiments. .

\section{Determination of the incorporation of isotopes into total} glycosaminoglycans of serum

Rats were injected intraperitoneally with either $37 \mathrm{MBq}$ of sodium $\left[{ }^{35} \mathrm{~S}\right]$ sulfate or $1.3 \mathrm{MBq}$ of $\left[{ }^{14} \mathrm{C}\right]$ glucosamine hydrochloride and decapitated at various times thereafter. $1-2 \mathrm{ml}$ of blood was collected from the neck vessels and non-hemolytic serum produced. The serum proteins were precipitated by addition of 5 vol. of acetone, centrifuged for $5 \mathrm{~min}$ at $3000 \mathrm{~g}$ and delipidized by washing consecutively with 5 vol. of ace- tone, chloroform-methanol (volumes, $200 \mathrm{ml}+100 \mathrm{ml}$ ) and ethanol-ether (volumes, $300 \mathrm{ml}+100 \mathrm{ml}$ ). The final sediment was dried at $60^{\circ} \mathrm{C}$, homogenized in $3 \mathrm{ml}$ of papain-buffer (10) from which an aliquot was taken for the determination of protein (11) and proteolysed for $24 \mathrm{~h}$ by the addition of $300 \mu \mathrm{l}$ (90 U) of papain (1). Total gly cosaminoglycans were isolated from the proteoly sate (1), dissolved in water and an aliquot was taken for the determination of $\left[{ }^{14} \mathrm{C}\right]-0 \mathrm{or}\left[{ }^{35} \mathrm{~S}\right]$-radioactivity in a liquid scintillation spectrometer with an efficiency of $81 \%$.

\section{Determination of the incorporation of isotopes into total glycosaminoglycans of liver}

After injection of the isotope the liver was quickly removed, chilled and minced in ice-cold buffer $(0.05 \mathrm{~mol} / 1$ Tris- $\mathrm{HCl}$, $\left.\mathrm{pH} 7.6\left(20^{\circ} \mathrm{C}\right), 0.08 \mathrm{~mol} / 1 \mathrm{KCl}, 0.0125 \mathrm{~mol} / 1 \mathrm{MgCl}_{2}\right)$, freed carefully of blood and homogenized at $2^{\circ} \mathrm{C}$. The protein was precipitated with 5 vol. of acetone and defatted and proteolysed as above. Gly cosaminoglycan-associated radioactivity .was isolated and counted as described for serum.

\section{Determination of the incorporation of isotopes into specific types of glycosaminoglycans of serum and liver}

As described elsewhere (1) total gly cosaminogly cans were subjected to enzymatic analysis with chondroitin $A B C$ and $A C$ lyases to determine the incorporation of label into chondroitin sulfate and dermatan sulfate, and degraded by nitrous acid to quantitate the incorporation into heparan sulfate and heparin. The incorporation of radioactivity into specific types of glycosaminoglycans was expressed as percentage of the activity of the unfractionated gly cosaminogly cans.

Total labeled gly cosaminogly cans of serum were chromatographed on a column $(0.6 \times 13 \mathrm{~cm})$ of Dowex $1 \times 2(\mathrm{Cl})$ by stepwise elution with an increasing molarity of $\mathrm{NaCl}(1,12)$. The fractions were dialyzed, dried, dissolved in water and subjected to enzymatic and chemical identification.

\section{Gel chromatography of serum glycosaminoglycans}

$13 \mathrm{ml}$ of serum from normal rats, which received [ ${ }^{35} \mathrm{~S}$ ] sulfate $5 \mathrm{~h}$ prior to decapitation, were applied to a column $(1.4 \times 60$ $\mathrm{cm})$ of Bio-Gel P 2 and eluted with high ionic strength buffer $A$ $\left(0.02 \mathrm{~mol} / 1 \mathrm{Tris}-\mathrm{HCl}, \mathrm{pH} 7.6\left(20^{\circ} \mathrm{C}\right), 0.5 \mathrm{~mol} / 1 \mathrm{KCl}, 0.003\right.$ $\mathrm{mol} / \mathrm{l} \mathrm{MgCl}_{2}$ ). The excluded radioactivity was concentrated by ultrafiltration (filter UM 2, Amicon $\mathrm{GmbH}$ ) and rechromatographed on a column $(2 \times 120 \mathrm{~cm})$ of Sepharose CL-4B. The activity eluted with buffer $A$ between 300 and $325 \mathrm{ml}$ was pooled, dialyzed and divided in two equal portions. One portion was rechromatographed on a column $(2 \times 120 \mathrm{~cm})$ of Sephadex G-100 after proteolytic digestion with $200 \mu \mathrm{l}(60 \mathrm{U})$ of papain for $48 \mathrm{~h}$ at $60^{\circ} \mathrm{C}$, the other one was treated identically but without addition of papain. The eluates were fractionated into $5 \mathrm{ml}$ portions and analy sed for radioactivity. All chromatographic procedures were performed at $4^{\circ} \mathrm{C}$.

\section{Density gradient centrifugation of serum glycosaminoglycans} The undigested radioactive material eluted with buffer $\mathbf{A}$ between 125 and $150 \mathrm{ml}$ from Sephadex G-100 was concentrated by ultrafiltration (filter PM 10) and adjusted to a starting density of $1.55 \mathrm{~kg} / \mathrm{l}$ by the addition of solid $\mathrm{CsCl}_{2}$. The gradients $(13 \mathrm{ml})$ were centrifuged for $60 \mathrm{~h}$ at $155000 \mathrm{~g}$ and $20^{\circ} \mathrm{C}$ and then fractionated into $1 \mathrm{ml}$ portions in which the density and radioactivity were determined. The fraction containing the peak activity was proteolysed and subjected to enzymatic analysis for chondroitin sulfate.

\section{Electrophoresis of $\left[{ }^{35} S\right]$-labeled serum components}

Serum was obtained from normal rats which recived [ $\left.{ }^{35} \mathrm{~S}\right]-$ sulfate $5 \mathrm{~h}$ before exitus. The proteins were separated by cellulose acetate foil electrophoresis following standard clinical laboratory procedures (13). The bands of more than 20 electropherograms were cut out, pooled and counted for radioactivity after addition of Instagel (Packard). 


\section{Results}

\section{Labeling pattern of specific glycosaminoglycans in liver and serum}

As previously reported $(1,2)$ rat liver explants do not incorporate $\left[{ }^{14} \mathrm{C}\right]$ hexosamine and only a very small fraction of $\left[{ }^{35} \mathrm{~S}\right]$ sulfate $(0.007-0.013$ of total glycosaminoglycans) into dermatan sulfate. The data shown in table 1 confirm the inability of rat liver to incorporate $\left[{ }^{14} \mathrm{C}\right]$ hexosamine into dermatan sulfate in vivo during a $1 \mathrm{~h}$ labeling period. However, using $\left[{ }^{35} \mathrm{~S}\right]$ sulfate as a precursor a fraction of about 0.15 of the total glycosaminoglycan radioactivity was found in dermatan sulfate. Both isotopes were incorporated predominantly into heparan sulfate $(0.70$ to 0.85$)$ the remainder being recovered in chondroitin sulfate (tab. 1).

The proportions did not change significantly in acutely injured liver (data not shown).

In serum of normal and liver-damaged rats $\left[{ }^{14} \mathrm{C}\right]$ glucosamine was incorporated exclusively into chondroitin sulfate. This type of serum glycosaminoglycan was also predominantly labeled after injection of $\left[{ }^{35} \mathrm{~S}\right]$ sulfate. Only a small fraction of $\left[{ }^{35} \mathrm{~S}\right] \mathrm{label}$ was found in serum dermatan sulfate and heparan sulfate (tab. 1).

Time course of $\left[{ }^{35} S\right]$ sulfate incorporation into serum glycosaminoglycans of normal and liver-damaged rats

Only $\left[{ }^{35} \mathrm{~S}\right]$ sulfate is incorporated both into liver and serum dermatan sulfate. Consequently this type of isotopic precursor was used in the following studies. $\left[{ }^{35} \mathrm{~S}\right]$ sulfate is incorporated very rapidly into serum glycosaminoglycans of normal rats (fig. 1). Nearly a fraction of 0.50 of the final radioactivity of serum glycosaminoglycans (at $300 \mathrm{~min}$ ) is reached within $45 \mathrm{~min}$ after application of the isotope.

Tab. 1. The pattern of incorporation of $\left[{ }^{14} \mathrm{C}\right]$ glucosamine and $\left[^{35}\right.$ S j sulfate into specific types of glycosaminogly.cans in liver and serum of normal rats. Rats received the isotopes $1 \mathrm{~h}$ before sacrifice. Glycosaminogly cans isolated from liver and serum were characterized by enzymatic and chemical procedures. The radioactivity incorporated into specific types is expressed as fraction of total glycosaminogly can-radioactivity. The ratios are the mean of triplicate experiments.

\begin{tabular}{|c|c|c|c|c|}
\hline $\begin{array}{l}\text { Isotopic } \\
\text { precựsor }\end{array}$ & & $\begin{array}{l}\text { Heparan } \\
\text { sulfate }\end{array}$ & $\begin{array}{l}\text { Chondrōitin } \\
\text { sulfate }\end{array}$ & $\begin{array}{l}\text { Dermatan } \\
\text { sulfate }\end{array}$ \\
\hline \multicolumn{5}{|c|}{$\left[{ }^{14} \mathrm{C}\right]$ Glucos samine } \\
\hline & Serumm & - & 1.00 & - \\
\hline & Liver & 0.725 & 0.042 & 0.152 \\
\hline \multicolumn{5}{|c|}{$\left[^{35}\right.$ S]Sulfate } \\
\hline & Serum & $0: 044$ & 0.85 & 0.065 \\
\hline
\end{tabular}

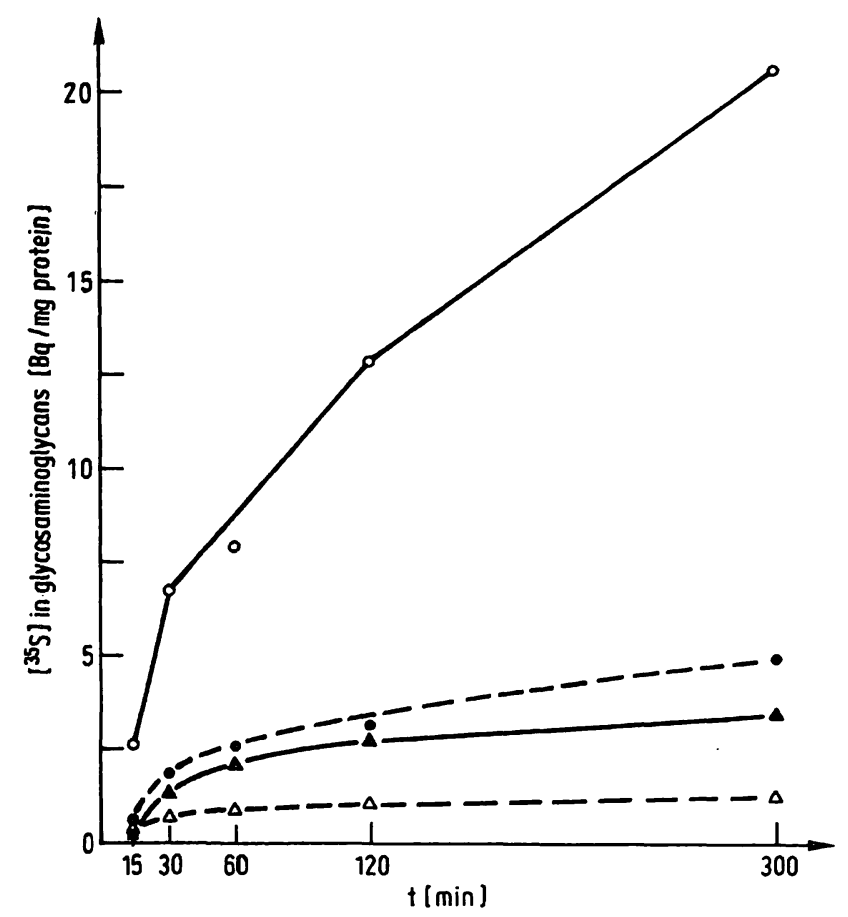

Fig. 1. Time course of $\left[{ }^{35} \mathrm{~S}\right]$ sulfate incorporation into total serum gly cosaminoglycans of normal $(\bullet---\bullet)$, acutely $(0-0)$, subacutely $(\Delta---\Delta)$ and chronically $(\Delta-\Delta)$ liver-injured rats.

The animals were sacrificed at various times after injection of the isotope, and the radioactivity incorporated into total serum glycosaminogly cans was determined and referred to the concentration of serum protein. The total serum protein concentration did not change under treatment.

Rate and extent of incorporation of sulfate into glycosaminoglycans are significantly augmented in acutely liver-damaged rats. $5 \mathrm{~h}$ after application of the isotope the activity of total serum glycosaminogly cans was over 4 times higher than normal (fig. 1).

In contrast, long- und middle-term liver damage resulted in a $30 \%$ and $75 \%$ reduction of the respective final activities of serum glycosaminoglycans (fig. 1).

The differences in the kinetics of sulfate incorporation into serum glycosaminoglycans of rats in different stages of liver injury become more complex if the timedependency of the labeling pattern of specific types of glycosaminoglycans is analysed (fig. 2). In normal rats a fraction of 0.65 of the sulfate incorporated within $15 \mathrm{~min}$ into serum glycosaminoglycans was found in chondroitin sulfate, the remainder being associated with dermatan sulfate. Concomitantly with a further time-dependent increase in the fraction of chondroitin $\left[{ }^{35} \mathrm{~S}\right]$ sulfate, the dermatan $\left[{ }^{35} \mathrm{~S}\right]$ sulfate disappears within $2 \mathrm{~h}$ from the circulation (fig. $2 \mathrm{a}$ ). No other sulfated gly cosaminoglycans could be detected in.serum in significant amounts.

In rats with acute liver injury the proportion of initially $\left[{ }^{35} \mathrm{~S}\right]$ labeled chondroitin sulfate was higher $(0.81)$ where- 


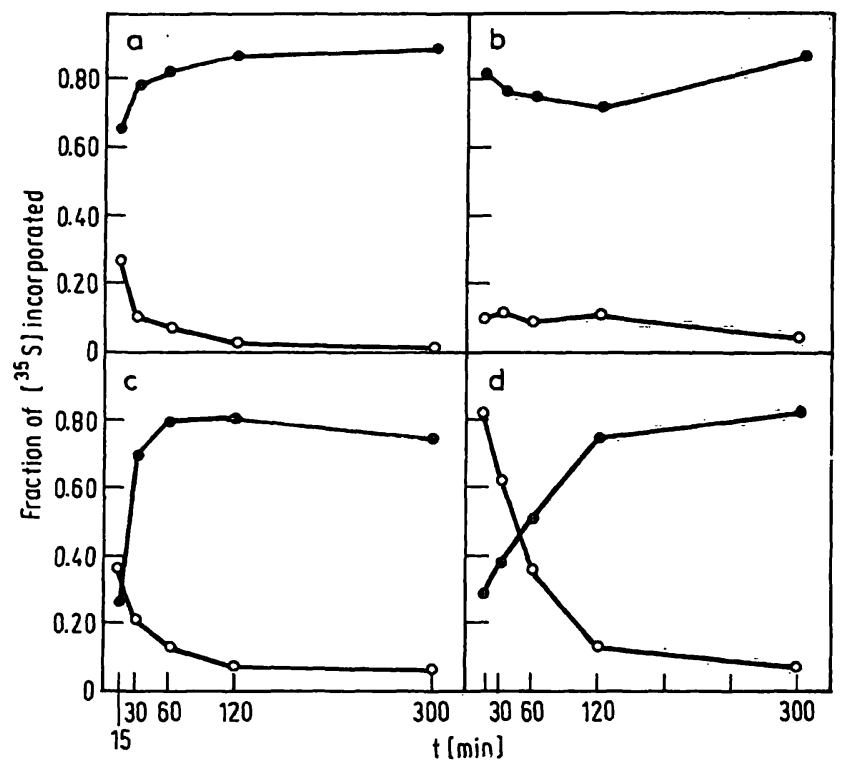

Fig. 2. Time course of the relative incorporation of $\left[{ }^{35} \mathrm{~S}\right]$ sulfate into specific types of serum gly cosaminogly cans of normal (a), acutely (b), subacutely (c) and chronically (d) liverinjured rats: The animals were treated as described in fig. 1, individual gly cosaminoglycans were identified by chemical and enzymatic procedures and expressed as a fraction of total gly cosaminoglycans. Chondroitin sulfate $\bullet-\bullet$ dermatan sulfate $0-0$.

as that of dermatan sulfate was lower (about 0.10) than normal. During a $5 \mathrm{~h}$ period the relative distribution did not change significantly (fig. $2 b$ ).

In animals with subacute and chronic liver damage the initial sulfation pattern was reversed, i.e. the fraction of labeled dermatan sulfate was greater than that of chondroitin sulfate (fig. $2 c, d$ ). In long-term liverinjured rats a fraction of 0.82 of $\left[{ }^{35}\right.$ S] sulfate incorpor- ated into total glycosaminoglycans was found initially (at $15 \mathrm{~min}$ ) in dermatan sulfäte, the remainder in chondroitin sulfate (fig. 2D). Since the fraction of circulating $\left[{ }^{35} \mathrm{~S}\right]$ dermatan sulfate declines more slowily in rats with chronic liver damage than in untreated animals, their relative level of serum dermatan $\left[{ }^{35} \mathrm{~S}\right]$ sulfate was found to be significantly elevated.

\section{Time course of $\left[{ }^{35}\right.$ S] sulfate incorporation into liver glycosaminoglycans}

The kinetics of sulfation of glycosaminoglycans in serum was studied in comparison to that in liver of injured rats. Figure 3 a demonstrates a highly active sulfation of glycosaminoglycans in liver which is detectable as early as $2 \mathrm{~min}$ after application of the isotope. In contrast, the sulfation of gly cosaminoglycans in $1-2 \mathrm{ml}$ of serum (protein concentration about $70 \mathrm{~g} / \mathrm{l}$ ) was not detectable until $10 \mathrm{~min}$ after injection of the label. At this time the activity $(\mathrm{Bq} / \mathrm{mg}$ protein) of total glycosaminoglycans in the liver was about 125 times higher than in serum (tab. 2).

Tab. 2. Ratio of incorporation of $\left[{ }^{35} \mathrm{~S}\right]$ sulfate into gly cosaminoglycans of liver and serum of chronically liver-damaged rats. The calculation is based on the data given in fig. 3 . The activity of glycosaminogly cans is expressed per $\mathrm{mg}$ of protein of liver or serum, respectively.

\begin{tabular}{|c|c|c|c|}
\hline \multirow{2}{*}{$\begin{array}{l}\text { Time } \\
\text { after application } \\
\text { of }\left[{ }^{35} \text { S ] sulfate }\right. \\
\text { (min) }\end{array}$} & \multicolumn{3}{|c|}{$\begin{array}{l}\text { Liver/serum ratios of radioactivity } \\
\text { (Bq/mg protein) } \\
\text { incorporated into glycosaminoglycans }\end{array}$} \\
\hline & Total & $\begin{array}{l}\text { Chondroitin } \\
\text { sulfate }\end{array}$ & $\begin{array}{l}\text { Dermatan } \\
\text { sulfate }\end{array}$ \\
\hline $\begin{array}{l}10 \\
15 \\
30 \\
60\end{array}$ & $\begin{array}{r}127 \\
63 \\
42 \\
74\end{array}$ & $\begin{array}{r}- \\
26 \\
6 \\
2\end{array}$ & $\begin{array}{l}- \\
16 \\
24 \\
45\end{array}$ \\
\hline
\end{tabular}

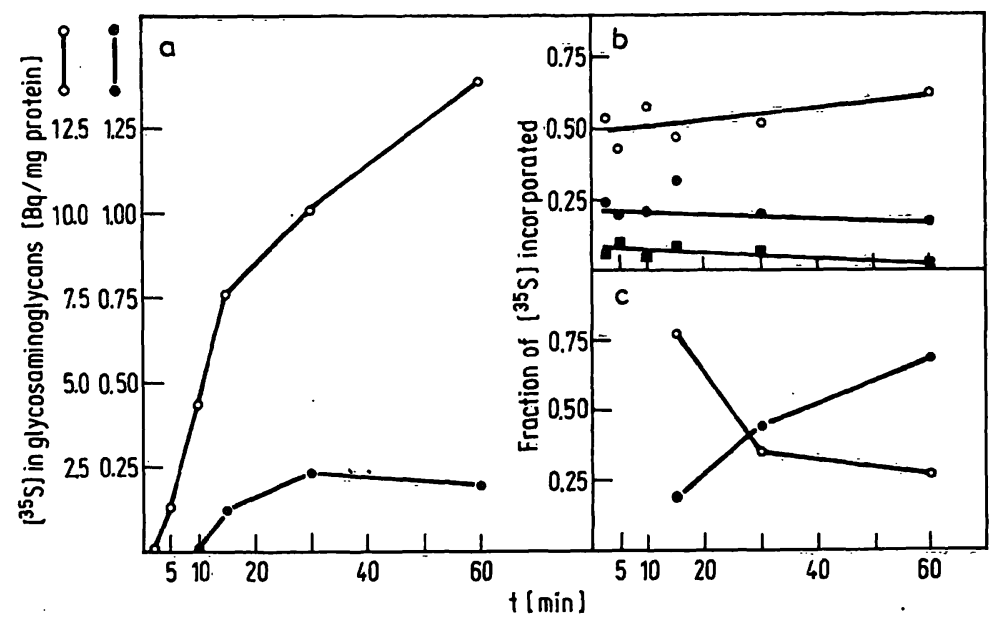

Fig. 3. Time course of [ $^{35} \mathrm{~S}$ ]sulfate incorporation into total and specific types of glycosaminoglycans in liver and serum of chronically injured rats. The animals were injected with $18 \mathrm{MBq}$ of $\left.{ }^{35} \mathrm{~S}\right]$ sulfate and decapitated at the times indicated. The radioactivity incorporated into total glycosaminoglycans (a) of serum $(\bullet-\bullet)$ and liver $(0-0)$ was determined. The incorporation into specific glycosaminoglycans of liver $(b, 0-0$ heparan sulfate, $-\infty$ dermatan sulfate, - chondroitin sulfate) and serum (c, ०—— dermatan sulfate, $-\longrightarrow$ chondrotin sulfate) is expressed as a fraction of the incorporation into total gly cosamino glycans. 
As illustrated in figure $3 b$ and $c$ the time courses of sulfation of individual glycosaminoglycans in liver and serum of chronically liver-injured rats are strikingly different. The ratios of incorporation of $\left[{ }^{35} \mathrm{~S}\right]$ sulfate into heparan sulfate, dermatan sulfate and chondroitin sulfate of liver were 1:0.34:0.09 and remained nearly unchanged with time. In serum, however, the relative distribution of $\left[{ }^{35} \mathrm{~S}\right]$ sulfate between chondroitin sulfate and dermatan sulfate reversed with time (fig. $2 \mathrm{~d}, 3 \mathrm{c}$ ).

The ratios of sulfation of liver- and serum-derived dermatan sulfate and chondroitin sulfate were calculated. The data summarized in table 2 indicate a much higher incorporation of sulfate into the glycosaminoglycan types of liver at any time. The liver/serum ratios exhibit a time-dependent increase for dermatan sulfate but a decrease for chondroitin sulfate.

\section{Proteoglycan character of serum glycosaminoglycans}

Results presented above demonstrate metabolic changes of serum glycosaminoglycans in rats with experimental liver injury. Further studies were performed to analyse the macromolecular and protein-bound nature of serum glycosaminoglycans and its possible alteration in liverdamaged animals.

Figure 4 shows that the peak $\left[{ }^{35} \mathrm{~S}\right]$ sulfate activity incorporated into serum components comigrates with the $\alpha_{1}$-globulin fraction regardless of the origin of the serum, i.e. from healthy or liver-damaged rats.

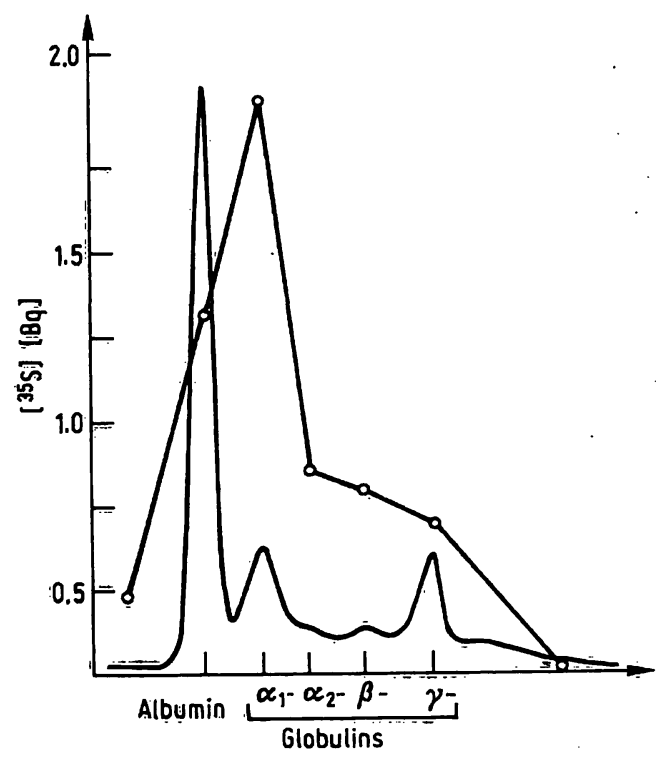

Fig. 4. Cellulose ācetate foil electrophoresis of $\left[{ }^{35}\right.$ S $]$-labeled components from rat serum. $5 \mathrm{~h}$ after i.p. injection of [ ${ }^{35}$ S] sulfate into a normal rat, blood was collected and about $50 \mu \mathrm{l}$ of serum electrophoretically separated. The protein fractions of about 20 electrophoreses were cut out and their radioactivity $(0-0)$ determined. A typical densitograph $(-)$ is illustrated. Essentially identical results were obtained with serum from liver-injured rats (not shown).
However, it is by no means certain that some if any of the activity of the $\alpha_{1}$-globulin is proteoglycan in nature. Therefore serum obtained from normal rats injected previously with $\left[{ }^{35} \mathrm{~S}\right]$ sulfate was chromatographed on Bio-Gel P2 to remove low molecular weight $\left[{ }^{35} \mathrm{~S}\right]$ sulfate labeled components (fig. 5). The excluded radioactivity was rechromatographed on Sepharose CL-4B. The fractions which contained chondroitin $\left[{ }^{35} \mathrm{~S}\right]$ sulfate (Kav $=0.76$ ) were further chromatographed on a column of Sephadex G-100 before (fig. 5c) and after (fig. 5d) proteolysis by papain. Extensive degradation to low

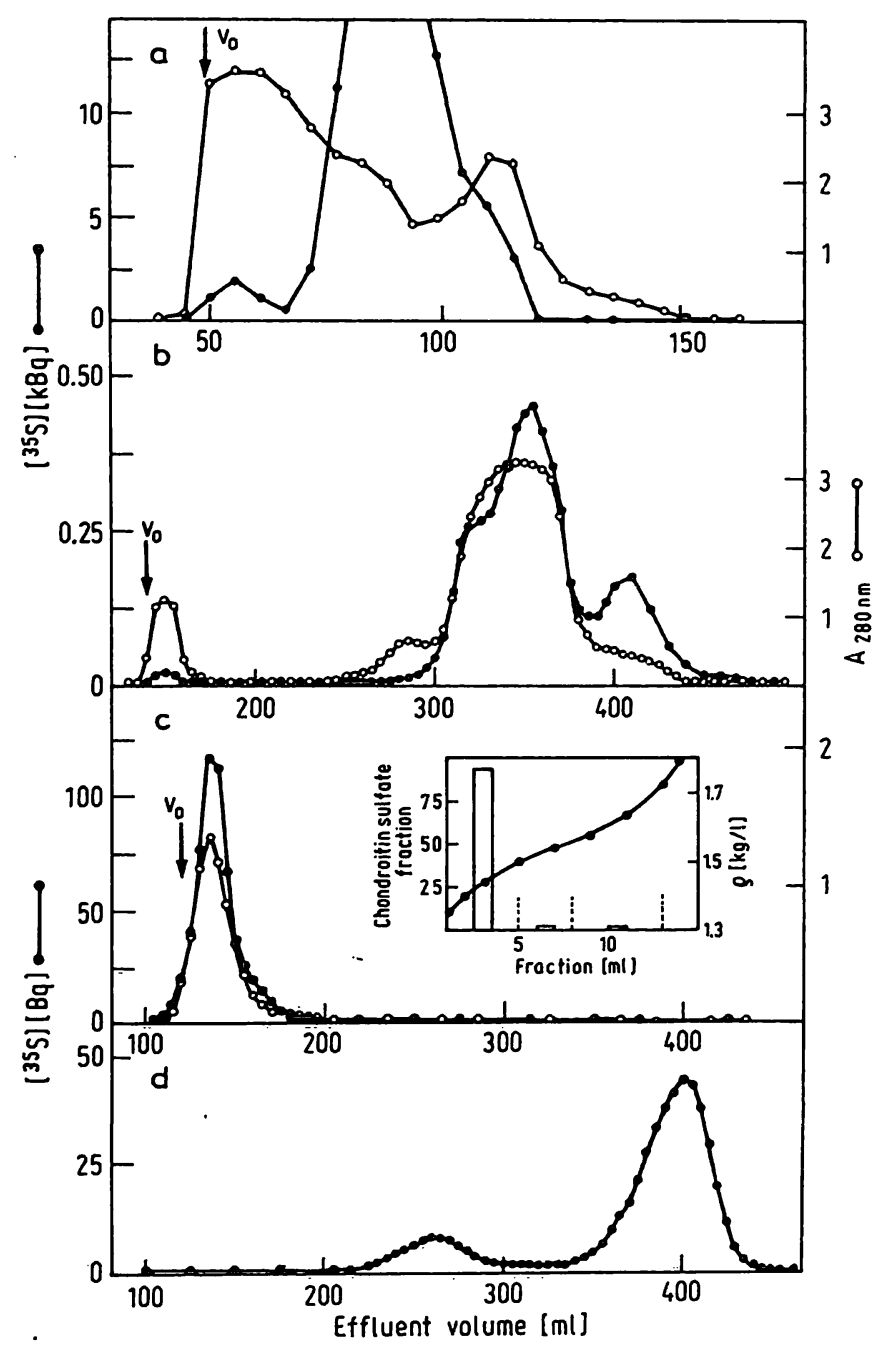

Fig. 5. Gel chromatography of $\left[{ }^{35}\right.$ S $]$ labeled glycosaminoglycans fróm normal rat serum.

The animals were decapitated $5 \mathrm{~h}$ after injection of $\left[{ }^{35} \mathrm{~S}\right]$ sulfate and blood was collected. $13 \mathrm{ml}$ of serum was applied to a column of Biogel P 2 and eluted with buffer $A$ $(0.02 \mathrm{~mol} / 1$ Tris- $\mathrm{HCl}, \mathrm{pH} 7.6,0.5 \mathrm{~mol} / 1 \mathrm{KCl}, 0.003 \mathrm{~mol} / \mathrm{l}$ $\mathrm{MgCl}_{2}$ ). The activity eluted between 50 and $70 \mathrm{ml}$ (a) was rechromatographed on a column of sepharose $\mathrm{CL}-4 \mathrm{~B}$ in buffer $A(b)$. The fractions between 300 and $325 \mathrm{ml}$ effluent were pooled and divided in two equal portions ( $a$ and $b$ ). Portion a was digested with papain prior to chromatography on Sephadex G 100 (d); portion b was treated identically but without addition of papain (c). The inset in c represents the distribution of the undigested chondroitin sulfate in $13 \mathrm{ml}$ of a $\mathrm{CsCl}$-density gradient $(\bullet-\bullet$, density). 
molecular weight fractions was observed after proteolytic treatment. The elution pattern of the undegraded chondroitin sulfate $(\mathrm{Kav}=0.05)(\mathrm{fig} .5 \mathrm{c})$ and degraded chondroitin sulfate (Kav $=0.55)$ (fig. $5 \mathrm{~d}$ ) was not changed by the addition of excessive amounts of unlabeled chondroitin sulfate and rat serum protein, respectively. It should be emphasized that after proteolysis a major radioactive peak of unknown identity occurred at $V_{t}(380 \mathrm{ml})$ of Sephadex G-100 (fig. 5d). The high molecular weight fraction of serum glycosaminoglycans, which was almost excluded from Sephadex G-100 (fig. 5c), was further characterized by isopycnic density gradient centrifugation under both associating and dissociating conditions (in the presence of $4 \mathrm{~mol} / \mathrm{l}$ of guanidinium hydrochloride). In each case a fraction of about 0.90 of the total chondroitin sulfate banded near the top of the gradient at a density of $d=1.44 \mathrm{~kg} / \mathrm{l}$ (inset in fig. $5 \mathrm{c}$ ). Neither the gel chromatographic elution pattern of serum glycosaminoglycans nor their distribution in isopycnic gradients showed any change under the influence of liver injury (results not shown).

However, differences were observed in the ion-exchange chromatographic behaviour of $\left[{ }^{35} \mathrm{~S}\right] \mathrm{gly}$ cosaminoglycans from serum of normal and acutely liver-injured rats. $\left[{ }^{35} \mathrm{~S}\right]$ labeled chondroitin sulfate from treated rats tended to elute at lower ionic strength $(0.5 \mathrm{~mol} / 1$ $\mathrm{NaCl}$ ) from Dowex $1 \times 2$ than the glycosaminoglycans isolated from normal rat serum (fig. 6).

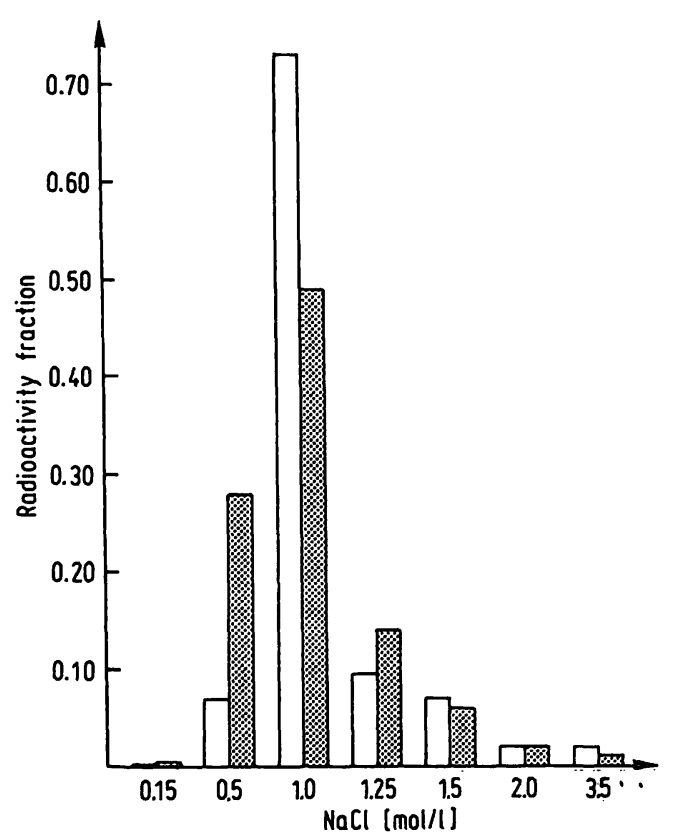

Fig. 6. Anion-exchange chromatography of $\left[{ }^{35} \mathrm{~S}\right]$-labeled glycosaminogly cans from serum of normal (open bars) and acutely liver-injured (hatched bars) rats.

The animals were decapitated $5 \mathrm{~h}$ after injection of $\left[{ }^{35} \mathrm{~S}\right]$ sulfate. Total gly cosaminoglycans (containing predominantly chondroitin sulfate) were isolated from serum, applied to a column of Dowex $1 \times 2$ and eluted with a stepwise gradient of increasing molarity of $\mathrm{NaCl}$. Fractions were assayed for radioactivity.

\section{Discussion}

Although distribution and chemical composition of acidic glycosaminoglycans in blood have been reported by several investigators (14-21) detailed information on their physiological functions, metabolism and pathobiochemical alterations are still lacking. It has been reported that human serum contains a preponderance of undersulfated chondroitin 4-sulfate and chondroitin 6-sulfate (21-23) and only a small amount of chondroitinase-resistant acidic gly cosaminoglycans (heparan sulfate, dermatan sulfate, keratan sulfate) $(20-22)$. Accordingly, we observed in normal rats a nearly exclusive incorporation of $\left[{ }^{35} \mathrm{~S}\right]$ sulfate and $\left[{ }^{14} \mathrm{C}\right]$ glucosamine into chondroitin sulfate. The source of serum glycosaminoglycans is unknown but it was suggested that they may derive at least in part from leukocytes or platelets $(21,23-25)$ or orginate from the extracellular matrices of various tissues. The sites of degradation (e.g. desulfation) of the different types of serum glycosaminoglycans are also not known but obviously glycosaminoglycan-degrading tissues are widespread in the body (26). Several studies indicate that the liver might have an important function in this process $(26,27)$.

Information on the concentration, composition and metabolism of glycosaminoglycans in serum of patients with liver disease or in serum of experimentally liverinjured rats is lacking. But from the increase of the urinary excretion of glycosaminoglycans in patients with chronic hepatitis or florid cirrhosis (28) concomitant alterations of the concentration and composition of glycosaminoglycans in serum can be deduced. Further studies are necessary to prove such changes and to elucidate their role in the pathogenesis of liver fibrosis.

Slices of normal and injured liver do not incorporate $\left[{ }^{14} \mathrm{C}\right]$ hexosamine and far less than a fraction of 0.01 of $\left[{ }^{35} \mathrm{~S}\right]$ sulfate into dermatan sulfate $(1,2,29)$. It might be possible that an as yet unidentified extrahepatic factor which promotes specifically the synthesis or sulfation of dermatan sulfate in liver is lacking in vitro, but it also seems likely that hepatic dermatan sulfate is supplied to the liver from extrahepatic sources. The present results indirectly support this assumption, since in vivo a fraction of about 0.15 of total liver $\left[{ }^{35}\right.$ S $]$ glycosaminoglycan activity is located in dermatan sulfate; also significant changes of the kinetics of sulfation of serum dermatan sulfate occur in chronically liverinjured rats, and the liver/serum ratio of dermatan $\left[{ }^{35} \mathrm{~S}\right]$ sulfate increases with time nearly 3 -fold, whereas that of chondroitin sulfate and of total glycosaminoglycan declines (tab. 2). However, the specificity of these serum changes for liver injury remains to be determined. From the data given in figure 3 the amount of labeled dermatan sulfate in the whole liver and in the total serum volume of a rat $(320 \mathrm{~g}$ body wt.) can be calculated, based on a rat plasma volume of $39 \mathrm{ml} / \mathrm{kg}$ body weight (30), a serum protein con- 
centration of $70 \mathrm{~g} / \mathrm{l}$ and a total liver protein of $1.1 \mathrm{~g}$. Accordingly 15, 30 and $60 \mathrm{~min}$ after injection of $\left[{ }^{35} \mathrm{~S}\right]$ sulfate the respective total amounts of dermatan $\left[{ }^{35} \mathrm{~S}\right]$ sulfate in the liver are 20-, 30-, and 57-fold, greater than in the whole body serum. This indicates that either serum dermatan sulfate cannot be the single source of liver dermatan sulfate or that dermatan sulfate coming from the serum is rapidly sulfated in the liver. Since neither liver - nor serum - dermatan sulfate incorporated $\left[{ }^{14} \mathrm{C}\right]$ hexosamine, its sulfate groups must turn over more rapidly than, and independently from, the carbohydrate chain. Thus incorporation of sulfate in this type of glycosaminogly can does not represent "de novo" synthesis, but sulfation of an already existing carbohydrate acceptor.

The experimental evidence for a supply of the carbohydrate chain acceptor to the liver via the systemic circulation, as suggested here, is rather circumstantial. Studies on the uptake and deposition of proteodermatan sulfate in normal and diseased liver, where it cannot be degraded by lysosomal enzymes $(31,32)$, are difficult at present, because homologous liver or serum proteodermatan sulfate is not available in amounts sufficient for intravenous injections or application to the medium of isolated perfused rat livers. The use of a glycosaminoglycan instead of native proteoglycan for such studies might lead to erroneous results since the metabolism

\section{References}

1. Gressner, A. M., Pazen, H. \& Greiling, H. (1977) HoppeSeyler's Z. Physiol. Chem. 358, 825-833.

2. Gressner, A. M., Pazen, H. \& Greiling, H. (1977) Experientia 33, 1290-1292.

3. Kjellén, L., Oldberg, A., Rubin, K. \& Höök, M. (1977) Biochem. Biophys. Res. Commun. 74, 126-133.

4. Koizumi, T., Nakamura, N. \& Abe, H. (1967) Biochim. Biophys. Acta $148,749-756$.

5. Kojima, J., Nakamura, N., Kanatani, M. \& Ohmori, K. (1975) Canc. Res. 35, 542-547.

6. Hutterer, F., Eisenștadt, M. \& Rubin, E. (1970) Experientia $26,244-245$

7. Suzuki, S., Suzuki, S., Nakamura, N. \& Koizumi, T. (1976) Biochim. Biophys. Acta 428, 166-181.

8. Hutterer, F. \& Bacchin, P. (1968) Fed. Proc. 27, 412.

9. Gressner, A. M., Köster, W., Van de Leur, E. \& Brúns, D. (1978) Fresenius Z. Anal. Chem. 290, 150-151.

10. Greiling, H. \& Stuhlșatz, H. W. (1969) Hoppe-Seyler's Z. Physiol. Chem. 350, 449-456.

11. Lowry, O. H., Rosebrough, N. J., Farr, A. L. \& Randall, R. J. (1951) J. Biol. Chem. 193, 265-275.

12. Ŝchiller, S., Slover, G. A. \& Dorfman, A. (1961) J. Biol. Chem. 236, 983-987.

13. Kaplan, A. \& Savory, J. (197.0), in Standard Methods of Clinical Chemistry (Mac Donald, R. P., ed.) Vol. 6, pp. 13-30, Academic Press; New York und London.

14. Badin, J., Schubert, M. \& Vouras, M. (1955) J. Clin. Invest. $34,1317-1323$.

15. Murata, K., Ogura, T. \& Okuyama, T. (1972) Biochem. Med. $6,223-230$.

16. Taniguchi, N., Moriya, N. \& Nanba, I. (1974) Clin. Chim. Acta $50,319-328$.

17. Juvani, M., Friman, G., Ranta, H. \& Wegelius, O: (1975) Biochim. Biophys. Acta 411, 1-10. of both types is quite different if injected intravenously $(33,34)$.

In the present study the macromolecular nature of serum gly cosaminoglycans was shown, which confirms the results of earlier reports $(20,21,23,35)$. Although glycosaminoglycans can interact electrostatically with a number of serum proteins (36) a covalent linkage to protein (core protein) seems likely since chondroitin sulfate radioactivity could not be displaced from protein by high amounts of the unlabeled counterpart (fig. $5 \mathrm{c}$ ). Furthermore, the readdition of serum protein to the glycosaminoglycan obtained after proteolysis was without effect on their gel chromatographic elution pattern (fig. $5 \mathrm{~d}$ ). The large amount of low molecular weight $\left[{ }^{35} \mathrm{~S}\right]$ labeled material liberated by proteolysis (eluting at $V_{t}$, fig. 5d) was not characterized further. It might partially originate from $\left[{ }^{35} \mathrm{~S}\right]$ sulfate entrapped by undegraded serum proteins, although chromatography was performed in buffers of high ionic strength. The material, however, might also derive from $\left[{ }^{35} \mathrm{~S}\right]$ containing oligosaccharides covalently linked to serum proteins. It is noteworthy that liver damage does not affect the macromolecular composition of serum gly cosaminoglycans, but some changes in the carbohydrate chain occur as indicated by the differences in the ion exchange chromatographic elution profiles (fig. 6).

18. Endo, M., Namiki, O. \& Yosizawa, Z. (1976) J. Biochem. $79,5-10$.

19. Singh, J., DiFerrante, N., Gyorkey, F. \& Wilson, N. (1977) Atherosclerosis 28, 319-324.

20. Calatroni, A., Donnelly, P. V. \& Di Ferrante, N. (1969) J. Clin. Invest. 48, 332-343.

21. Murata, K. \& Horiuchi, Y. (1977) Clin. Chim. Acta 75, $59-69$.

22. Hata, R. \& Nagai, Y. (1978) Biochim. Biophys. Acta 543, 149-155.

23. Hata, R., Ohkawa, S. \& Nagai, Y. (1978) Biochim. Biophys. Acta 543, 156-166.

24. Murata, K. (1974) Clin. Chim. Acta 57, 115-124.

25. Murata, K., Ogura, T. \& Okuyama, T. (1974) Connect. Tiss. Res. 2, 101-109.

26. Perry, M. A., Powell, G. M., Wusteman, F. S. \& Curtis, C. G. (1977) Biochem. J. 166, 373-379.

27. Teien, A. N. (1977) Thromb. Haemostas. 38, 701-706.

28. Kawata, H., Koizumi, T., Wada, R. \& Yoshida, T. (1961) Gastroenterology 40, 507-512.

29. Gressner, A. M., Schulz, W. \& Greiling, H. (1979) Mech. Ageing Develop. 10, 445-450.

30. Wang, L. (1959) Am. J. Physiol. 196, 188-192.

31. Hutterer, F. (1966) Biochim. Biophys. Acta 115, 312-317.

32. Aronson, N. N. \& Davidson, E. A. (1968) J. Biol. Chem. 243, 4494-4499.

33. Revell, P. A. \& Muir, H. (1972) Biochem. J. 130, 597-606.

34. Wood, K. M., Wusteman, F. S. \& Curtis, C. G. (1973) Biochem. J. 134, 1009-1013.

35. Dziewiatkowski, D. D. \& Di Ferrante, N. (1957) J. Biol. Chem. 227, 347-356.

36. Lindahl, U. \& Höök, M. (1978) Ann. Rev. Biochem. 47, $385-417$.

Priv.-Doz. Dr. Axel M. Gressner

Abteilung Klinische Chemie und Pathobiochemie der Medizinischen Fakultät der RWTH Aachen Goethestr. 27-29

D-5100 Aachen 
